\title{
Primatology
}

\section{Why Primates Don’t Fly}

\section{Bruce M. Rothschild ${ }^{1,2 *}$, David A. Burnham ${ }^{1}$, Amanda R. Falk ${ }^{1,3}$, Larry D. Martin ${ }^{1,4}$, Robert M. Timm ${ }^{1,4}$}

${ }^{1}$ University of Kansas, Biodiversity Institute, 1345 Jayhawk BIVd, Lawrence, KS 66045, USA

${ }^{2}$ Northeast Ohio Medical University, Rootstown, OH 44505, USA

${ }^{3}$ Department of Geology, University of Kansas, Lawrence, KS 66045, USA

${ }^{4}$ Department of Ecology and Evolutionary Biology, University of Kansas, Lawrence, KS, USA

Primates have an especially long and highly arboreal evolutionary history [1], parallel to that of birds [2]. Birds developed powered flight, whereas primates had less lofty aims. Birds and primates are analogously wired for shoulder muscle functions that initially supported climbing and that were subsequently adapted for aerial activity [3-7]. Novel differences in pectoral girdle anatomy advantageous bird flight through ecotrophism. Ecotrophism is the propensity for life to expand into ecologic niches, with analogous organisms, but not necessarily related to or by the same evolutionary pathway.

Vertical clinging and climbing in primates correlates with an increase in vertebral body size caudally; dorsoventrally-shallow cervical and lumbar vertebrae; caudally-oriented spinal process on the axis; cranially-oriented post-diaphragmatic vertebrae with broad mediolateral, but short craniocaudal facets; peculiar pedicular origin of lumbar vertebrae transverse processes; elongated tail; and caudally-shifted center of gravity [8]. Other than orientation of postdiaphragmatic vertebrae (which of course does not apply to birds), birds manifest the same anatomical features [9] but have modified their shoulder girdles more successfully in terms of flight [10] by rotating their scapulae to eventually allow high-flapping (e.g., wings beats over their back).

The primate humerus is mobile with powerful and sustained extension and flexion at shoulder and elbow [8]. Stability is enhanced by greater space for attachment of rotator cuff muscles on tuberosities (e.g., lesser tuberosity expansion provides origin for the subscapularis, which extends, adducts, and medially rotates humerus). Bird humeri have a large pectoral crest that serves as an attachment point for both them. pectoralis and them. deltoideus (pars major). The deltapectoral crest also contains a tubercle that is the insertion point of them. supracoracoideus, the major wing-raising muscle in modern birds [11]. In birds, the flight motion is primarily a figure- 8 rotational movement [10]. This requires the interaction of different muscles in comparison to the strict up-and-down pulling motion associated with arboreal climbing.

Far more primates pursued behaviors that were arboreal rather than terrestrial with only one example of soaring (e.g., Propithecus; ) [10], whereas persistently arboreal birds developed powered flight. The relative safety of arboreal existence stimulated behaviour, whereas the time spent on the ground is allowed to avoid. The natural extrapolation of leaping from tree to tree was the development of anatomical modifications that extended their aerial range [11,12], leading to soaring. In contrast to birds, which rapidly became a successful radiation, primates evolved more slowly. By then, the environment had changed to more open habitats (e.g., savannahs) and the ecotrophism for development of flight was much reduced. Further, the expanded dietary opportunities in open environments advantaged terrestrial foraging. Development of feathers in birds eventually provided birds with the capability to forage in terrestrial environments; however, the patagium essential for primate flight (i.e., gliding) precluded utilization of the new environment, kept the shoulder girdle from rotating dorsally, and prevents rotational movement of the humerus found so critical to avian flight. Neither flying foxes nor flying lemurs (Colugos, order Dermoptera, the closest living relatives to primates) [13] can function as cursors. Even the most aerial of mammals (e.g., bats) are severely handicapped on the ground.

Arboreality, gliding, and powered flight lead to increased longevity. Flightlessness in primates did not increase mortality because increase in body size and socialization lowered their risk of life on ground (e.g., from predation), as has been noted in birds that became flightless [14]. Primates have "evolved physiological, social and behavioral defenses against predation" $[1,15,16]$. Conversely, the asocial flying lemur's reliance on low quality food (leaves) and tree holes for den sites and now the effects of deforestation subjects them to a more marginal existence [17].

Flight in both primates and birds developed from trees down, not from ground up $[2,18]$. Aerial forms always retain functional structures permitting movement in their ancestral environment [12]. All vertebrate classes have developed flight $[12,16]$. This ecotrophism includes development of soaring 10 times and true flight, 7 times. Primates similarly started down this evolutionary pathway, but were distracted by the opportunities offered by more open environments and all but one remained flightless.

\section{References}

1. Shattuck MR, Williams SA (2010) Arboreality has allowed for the evolution of increased longevity in mammals. Proc Natl Acad Sci 107.

2. Gong EP, Martin LD, Burnham DA, Falk AR, Hou LH (2012) A new species of Microraptor from the Jehol Biota of northeastern China. Palaeoworld 21: 81-91.

3. Buhl EH, Dann JF (1991) Cytoarchitecture, neuronal composition, and entorhinal afferents of the flying fox hippocampus. Hippocampus 1: 131-152.

4. Pettigrew JD (1991) Wings or brains? Convergent evolution in the origin of bats. Systematic Zool 40: 199-216.

5. Pettigrew JD (1986) Flying primates? Megabats have the advanced pathway from eye to midbrain. Science 231: 1304-1306.

6. Pettigrew JD, Jamieson BG (1987) Are flying foxes really primates? Aust Mammal 10: 119-124.

7. Rosa MG, Schmid LM, Krubitzer LA, Pettigrew JD (1993) Retinotopic organization of the primary visual cortex of flying foxes (Pteropus poliocephalus and Pteropus scapulatus). J Comp Neurol 331: 55-72.

8. Bloch JI, Boyer DM (2007) New skeletons of Paleocene-Eocene

*Corresponding author: Bruce M. Rothschild, University of Kansas, Biodiversity Institute, 1345 Jayhawk BIvd, Lawrence, KS 66045, USA, E-mail: bmr@ku.edu

Received September 20, 2012; Accepted September 24, 2012; Published September 26, 2012

Citation: Rothschild BM, Burnham DA, Falk AR, Martin LD, Timm RM (2012) Why Primates Don't Fly. J Primatol 1:e116. doi:10.4172/2167-6801.1000e116

Copyright: (c) 2012 Rothschild BM, et al. This is an open-access article distributed under the terms of the Creative Commons Attribution License, which permits unrestricted use, distribution, and reproduction in any medium, provided the original author and source are credited. 
Citation: Rothschild BM, Burnham DA, Falk AR, Martin LD, Timm RM (2012) Why Primates Don't Fly. J Primatol 1:e116. doi:10.4172/2167$6801.1000 \mathrm{e} 116$

Page 2 of 2

Plesiadapiformes: A diversity of arboreal positional behaviors in early primates. Springer, New York, 535-581.

9. Proctor NS, Lynch PJ (1993) Manual of Ornithology. Yale University Press, New Haven.

10. Zhou Z, Farlow J (2001) Flight capabilities and habits of Confuciusornis, new perspectives on the Origin and Early Evolution of Birds. A special publication of the Peabody Museum of Natural History Yale University, New Haven, 237-254.

11. Van den Berge JC, Zweers GA (1993) Myologia, Handbook of Avian anatomy. Nuttall Ornithological Club, Cambridge, 191-247.

12. Lull RS (1906) Volant adaptation in vertebrates. Amer Nat 40: 537-566.

13. Bloch JI, Boyer DM (2002) Grasping primate origins. Science 298: 1606-1610.

14. Szalay FS, Dagosto M (1988) Evolution of hallucial grasping in the primates. J Hum Evol 17: 1-33.

15. Janečka JE, Miller W, Pringle TH, Wiens F, Zitzmann A, et al. (2007) Molecular and genomic data identify the closest living relative of primates. Science 318 792-794.

16. Dudley R, Byrnes G, Yanoviak SP, Borrell B, Brown RM, et al. (2007) Gliding and the Functional Origins of Flight: Biomechanical novelty or necessity? Annu Rev Ecol Evol Syst 38: 179-201.

17. Smuts BB, Cheney DL, Seyfarth RM, Wrangham RW (1987) Predation, Primate Societies. Univ Chicago Press, 227-239.

18. Isbell LA (1994) Predation on primates: Ecological patterns and evolutionary consequences. Evol Anthropol 3: 61-71.

19. Byrnes G, Lim NT-L, Spence AJ (2008) Take-off and landing kinetics of a freeranging gliding mammal, the Malayan Colugo (Galeopterus variegatus). Proc Roy Soc B: Biol Sci 275: 1007-1013.

20. Xu X, Zhou Z, Wang X, Kuang X, Zhang F, et al. (2003) Four-winged dinosaurs from China. Nature 421: 335-340.
Submit your next manuscript and get advantages of OMICS Group submissions

Unique features:

User friendly/feasible website-translation of your paper to 50 world's leading languages

Audio Version of published paper

Digital articles to share and explore

Special features:

200 Open Access Journals

15,000 editorial team

21 days rapid review process

Quality and quick editorial, review and publication processing

Indexing at PubMed (partial), Scopus, DOAJ, EBSCO, Index Copernicus and Google Scholar etc

Sharing Option: Social Networking Enabled

- Authors, Reviewers and Editors rewarded with online Scientific Credits

Buthors, Reviewers and for your subsequent articles

Submit your manuscript at: http://omicsgroup.info/editorialtracking/primatology 